Diklus: Jurnal Pendidikan Luar Sekolah, 2(1), Maret 2018 - 12

Bima Suka Windiharta

\title{
PENDAMPINGAN ORANG TUA DALAM MENANAMKAN NILAI-NILAI RELIGIUSITAS PADA ANAK DIDIK DI DESA TAMBI KECAMATAN KEJAJAR KABUPATEN WONOSOBO JAWA TENGAH
}

\section{PARTNERSHIP OF PARENTS IN PLANTING RELIGIUSITY VALUES IN CHILDREN IN THE VILLAGE OF TAMBI DISTRICT GOVERNMENT DISTRICT OF WONOSOBO JAWA CENTRAL}

\author{
Oleh: \\ Bima Suka Windiharta, Universitas Negeri Yogyakarta, \\ bimarageljaya@gmail.com
}

\begin{abstract}
Abstrak
Penelitian ini bertujuan untuk memperoleh informasi tentang cara dan upaya orang tua dalam mendampingi anak didik, agar nilai-nilai religiusitas tertanam pada diri anak didik di desa Tambi, Kejajar, Wonosobo. Penelitian ini merupakan penelitian deskriptif dengan pendekatan kualitatif. Pengumpulan data dilakukan dengan menggunakan teknik observasi, wawancara dan dokumentasi. Teknik yang digunakan dalam analisis data adalah reduksi data, penyajian data dan penarikan kesimpulan. Trianggulasi yang digunakan untuk menjelaskan keabsahan data dengan menggunakan triangulasi sumber dan triangulasi teknik. Hasil penelitian menunjukkan bahwa: (1) pendampingan orang tua meliputi pendampingan secara langsung melalui perilaku kegamaan yang dapat langsung dicontoh oleh para anak didik. Selain itu, orang juga melakukan dengan cara memberikan keteladanan langsung kepada anak didik, melalui berbagai macam kegiatan keagamaan. Orang tua juga melakukan pemahaman keagamaan melalui lembaga pendidikan seperti TPQ dan Madin (Madrasah Diniyah) (2) Faktor pendukung yaitu: (a) kondisi desa Tambi yang kondusif, (b) banyak kegiatan keagamaan, (c) terdapat lembaga kegamaan. (3) Faktor penghambat yang mempengaruhi pengelolaan adalah terbatasnya sarana penunjang kegiatan. (4) Hasil pendampingan orang tua dalam menanamkan nilainilai religiusitas pada diri anak didik, sudah dapat dikatakan berhasil, karena anak didik selain pemahaman kegamaannya baik, mereka juga dapat berperilaku sesuai dengan tuntunan agama.
\end{abstract}

Kata kunci : pendampingan orang tua, nilai-nilai religiusitas, anak didik, desa Tambi.

\begin{abstract}
This study aims to obtain information about the ways and efforts of parents in assisting students, so that the values of religiosity embedded in the students in the village Tambi, Kejajar, Wonosobo. This research is descriptive research with qualitative approach. The data were collected using observation, interview and documentation techniques. Techniques used in data analysis are data reduction, data presentation and conclusion drawing. Triangulation is used to explain the validity of data by using source triangulation and triangulation techniques. The results showed that: (1) parental assistance includes direct assistance through the behavior of the equality that can be directly modeled by the students. In addition, people also do by way of providing exemplary directly to students, through various religious activities. Parents also conduct religious understanding through educational institutions such as TPQ and Madin (Madrasah Diniyah). (2) Supporting factors are: (a) Conducive condition of Tambi village, (b) many religious activities, (c) religious institutions. (3) Inhibiting factors that affect management are the limited facilities supporting activities. (4) The result of parental assistance in instilling the values of religiosity in the students themselves, can be said to succeed, because students in addition to good understanding of the good, they can also behave in accordance with the guidance of religion.
\end{abstract}

Key words : parent assistance, religious values, students, Tambi village.

\section{PENDAHULUAN}

Pendidikan agama merupakan

pendidikan yang utama yang sangat

dibutuhkan bagi anak, dimana hal tersebut secara langsung berpengaruh terhadap perilaku dan perkembangan anak. Pendidikan beragama pada anak merupakan awal 


\section{Diklus: Jurnal Pendidikan Luar Sekolah, 2(1), Maret 2018 - 13 Bima Suka Windiharta}

pembentukan kepribadian, baik atau buruk kepribadian anak tergantung pada orang tua serta lingkungan yang mengasuhnya. Oleh karena itu sebagai orang tua mempunyai kewajiban memberikan pendidikan dan bimbingan kepada anak. Mengingat pentingnya pendidikan agama, maka orang tua harus mempunyai pengetahuan yang cukup dalam menegakan pilar-pilar pendidikan agama dalam lingkungan anak entah itu dalam keluarga maupun bermasyarakat.

Selain itu perkembangan teknologi yang sekarang ini merajalela membuat pengaruh besar pada masyarakat. Suatu hal yang tidak dapat dipungkiri bahwa pembangunan di segala bidang, manfaatnya semakin dirasakan oleh semua kalangan. Revolusi informasi menyebabkan dunia terasa semakin kecil, semakin mengglobal dan sebaliknya privacy seakan tidak ada lagi. Berkat revolusi informasi. Kini orang telah terbiasa berbicara tentang globalisasi dunia dengan modernisasi sebagai ciri utamanya.

Dengan teknologi informasi yang semakin cangih, hampir semua yang terjadi di pelosok dunia segera diketahui dan ketergantungan antar bangsa semakin besar. Untuk itu diperlukan sebuah pendidikan keagamaan yang tumbuh dan berkembang tidak hanya di dalam sekolah, melainkan juga di dalam lingkungan keluarga dan masyarakat. Pendidikan keagaamaan atau biasa disebut sebagai religiusitas, dalam Islam religiusitas pada garis besarnya tercermin dalam pengalaman akidah, syari'ah dan akhlak, atau dengan ungkapan lain; iman, Islam dan ihsan.
Bila semua unsur itu telah dimiliki oleh seseorang, maka dia dapat menjadi insan yang bergama yang sesungguhnya (dalam Efendi, 2008: 12).

Keluarga memiliki fungsi diantaranya adalah pertama, keluarga berfungsi untuk mengatur penyaluran dorongan seks, tidak ada masyarakat yang memperbolehkan seks sebebas-bebasnya antara siapa saja dalam masyarakat. Kedua, reproduksi berupa pengembangan keturunan pun selalu dibatasi dengan aturan yang menempatkan kegiatan ini dalam keluarga. Ketiga, keluarga berfungsi untuk mensosialisasikan anggota baru masyarakat sehingga dapat memerankan apa yang diharapkan darinya. Keempat, keluarga mempunyai fungsi afeksi: keluarga memberikan cinta kasih pada seorang anak. Kelima, keluarga memberikan status pada anak bukan hanya status yang diperoleh seperti status yang terkait dengan jenis kelamin, urutan kelahiran dan hubungan kekerabatan tetapi juga termasuk didalamnya status yang diperoleh orang tua yaitu status dalam kelas sosial tertentu. Keenam, keluarga memberikan perlindungan kepada anggotanya, baik perlindungan fisik maupun perlindungan bersifat kejiwaan (Kamanto Sunarto, 2004: 6364).

Berdasarkan pengamatan peneliti sewaktu melakukan observasi di Desa Tambi, Kecamatan Kejajar, Kabupaten Wonosobo, Jawa Tengah, diperoleh data sebagai berikut: Pertama, bahwa masyarakat desa Tambi secara pemahaman keagamaan mayoritas beragama Islam, dan tingkat religiusitasnya sangat tinggi. 


\section{Diklus: Jurnal Pendidikan Luar Sekolah, 2(1), Maret 2018 - 14 Bima Suka Windiharta}

Hal itu dibuktikan dengan beberapa tempat yang mengadakan pengajian, seperti Masjid, Mushalla, dan Ruma-rumah warga. Namun terdapat permasalahan yang dirasa cukup meresahkan para orang tua pada khusunya, dan masyarakat pada umumnya. Masalah tersebut berkaitan dengan kenakalan anak- anak, baik yang masih kecil maupun sudah remaja dan dewasa. Tidak hanya terbatas pada hal-hal yang bersifat ritualistic (ibadati), melainkan juga menyangkut hubungan social yang terjalin atas dasar nilai-nilai keagamaan. Namun, ada sebuah fenomena yang membuat religiusitas yang dipeluk masyarakat menjadi tercoreng. Terdapat aktivitas-aktivitas warga desa terutama anak-anak yang tidak mematuhi ajaran agama, seperti sholat, mengaji, dan menghormati yang lebih tua.

Hal itu disebabkan oleh gaya hidup modernitas yang sudah tidak bisa ditanggulangi oleh masyarakat. Masuknya produk-produk modern seperti Playstation, Gadget, Handpone, dan lain sebagainya, membuat anak-anak desa Tambi tergiur untuk memilikinya dan memainkan segala konten yang ada di dalamnya. Bahkan penulis menyaksikan sendiri kehidupan anak-anak desa menjadi semakin individualis, dan tidak mengenal tata-krama, serta sering melakukan kegiatan tawuran antar sesama.

Berdasarkan uraian diatas, maka penulis tertarik untuk meneliti dan mengakaji mangenai "Bentuk Pendampingan Orang Tua dalam Mengembangkan Nilai-nilai Religiusitas Pada Anak di Desa Tambi Kecamatan Kejajar Kabupaten Wonosobo"

\section{METODE PENELITIAN}

\section{Jenis Penelitian}

Pendekatan penelitian yang digunakan dalam penelitian ini adalah pendekatan kualitatif dengan metode yang digunakan adalah metode penelitian deskriptif kualitatif. Lexy J Moleong (2012:6) mendefinisikan penelitian kualitatif sebagai penelitian yang bermaksud untuk memahami fenomena tentang apa yang dialami oleh subyek penelitian misalnya perilaku, persepsi, motivasi tindakan, dll., secara holistic, dan dengan cara deskripsi dalam bentuk kata-kata dan bahasa, pada suatu konteks khusus yang alamiah dan dengan memanfaatkan berbagai metode ilmiah.

\section{Subjek dan Objek Penelitian}

Subyek yang digunakan dalam penelitian ini adalah dari orang tua anak didik di desa Tambi. Peneliti menentukan secara mandiri subyek penelitian yang akan digunakan untuk mencari informasi yang terkait dengan penelitian dengan pertimbangan-pertimbangan tertentu. Mengingat keterbatasan waktu, tenaga, biaya dan kemampuan peneliti maka pada penelitian ini pemilihan subyek dilakukan dengan purposive sampling.

\section{Setting, Waktu, dan Tempat Penelitian}

Penelitian ini dilaksanakan pada bulan Desember 2016- Maret 2017 di Desa Tambi, Kecamatan Kejajar, Kabupaten Wonosobo. Pertimbangan lokasi tersebut berdasarkan pertimbangan bahwa Desa Tambi merupakan 


\section{Diklus: Jurnal Pendidikan Luar Sekolah, 2(1), Maret 2018 - 15 Bima Suka Windiharta}

desa yang menyandang desa terbaik di kabupaten Wonosobo

\section{Metode Pengumpulan Data}

Jenis penelitian ini adalah deskriptif kualitatif. Semua data diperoleh melalui teknik wawancara, observasi partisipatif dan dokumentasi.

Sumber data yang dipergunaan adalah data primer yang diperoleh melalui wawancara dan observasi di desa Tambi. Selain itu, sumber data sekunder diperoleh melalui buku, internet, dokumentasi dari desa Tambi.

Instrumen penelitian adalah peneliti sendiri. Peneliti sebagai human instrument berfungs menetapkan fokus penelitian, memilih subyek penelitian sebagai sumber data, melakukan pengumpulan data, menilai kualitas data, dan membuat kesimpulan dari beberapa temuan.

\section{Teknik Analisis Data}

Untuk mengecek keabsahan data, peneliti menggunakan teknik pemeriksaan triangulasi sumber dan teknik. Trianggulasi data dilakukan dengan cara membandingkan data hasil penelitian dan mengecek informasi data hasil yang diperoleh dari: Wawancara dengan hasil observasi, demikian pula sebaliknya, membandingkan apa yang disampaikan oleh setiap subyek penelitian, dan membandingkan hasil wawancara, observasi dan dokumentasi yang didapatkan selama melakukan penelitian.
Teknik analisis data yang digunakan dalam penelitian ini menggunakan teknik analisis data meliputi data reduksi data, penyajian data dan penarikan kesimpulan.

\section{HASIL PENELITIAN DAN PEMBAHASAN}

1. Bentuk-bentuk Pendampingan Orang Tua dalam Mengembangkan Nilai- nilai Religiusitas Pada Anak Didik di Desa Tambi

Untuk mengetahui identitas bentuk- bentuk pendampingan orang tua dalam mengembangkan sikap religiusitas pada anak didik, maka diperlukan gambaran yang bersifat ideal yang dimiliki individu sebagai orang yang menduduki suatu posisi sosial. Seorang individu memiliki sejumlah identitas peran yang berhubungan dengan berbagai posisi sosial yang mereka miliki dan berbeda beda menurut tingkatan dalam perbandingannya satu sama lain. Identitas peran ini diungkapkan secara terbuka dalam melaksanakan peran dan membantu menentukan pentingnya suatu identitas peran tertentu dalam konsep diri seseorang secara keseluruhan (Doyke Paul Johnson, 1986: 38).

Sesuai dengan hasil observasi langsung peneliti ke desa Tambi, Kec. Kejajar, Kab. Wonosobo, bentuk dari pendampingan orang tua bermacam-macam tidak seragam begitu saja. Hal itu dipengaruhi oleh kondisi sosial-ekonomi dan keagamaan yang ada di 


\section{Diklus: Jurnal Pendidikan Luar Sekolah, 2(1), Maret 2018 - 16 Bima Suka Windiharta}

dalam keluarga yang bersangkutan. Hasil penelitian sebagai berikut:

\section{a. Perilaku Keagamaan}

Salah satunya pola didik yang bersifat religiusitas yaitu perilaku keagamaan yang diberikan orang tua untuk bekal anak mereka dalam kehidupan bermasyarakat kelak. Pendidikan agama dirasa sangatlah penting apalagi dalam kehidupan yang kritis seperti sekarang ini. Setiap orang tua sangat menginginkan anaknya dapat hidup bermasyarakat dengan baik, banyak cara yang ditempuh orang tua dalam menanamkan sikap beragama sejak dini pada anaknya.

Setiap orang tua seperti bapak sunyoto yang mempunyai anak didik tersebut memang menginginkan anaknya kelak menjadi anak yang baik dalam kehidupannya, agar menjadi anak yang sesuai dengan harapan orang tua. Hal itu juga ditengarai agar menghindari anak didik dari perilaku atau perbuatan yang negatif. Apalagi di era yang serba instan seperti sekarang ini, perilaku keagamaan sangatlah penting untuk diajarkan kepada anak sedini mungkin.

Tidak dapat dipungkiri bahwa di desa Tambi pergaulan anak didik sudah tidak bisa dibatasi, karena di desa ini sudah masuk berbagai macam kemodernan, sehingga anak didik dapat dengan mudah mengakses segala sesuatu dan berhubungan dengan siapapun. Sehingga diperlukan kesadaran akan perilaku keagamaan sejak dini untuk menjaga agar anak didik tidak terjerumus dengan pergaulan.

Sebagai contoh IPNU dan IPPNU, sebagai basis pengkaderan kader NU, serta untuk mengajarkan perilaku keagamaan kepada generasi anak muda di desa Tambi. Selain itu juga terdapat, Paguyuban Anak Desa Islami (PADI), yang tujuan awal dibentuknya komunitas tersebut untuk menjadikan generasi muda desa Tambi mempunyai akhlak-akhlak islami yang sesuai dengan ajaran Islam. Tidak hanya yang berbentuk komunitas atau organisasi agama tersebut, di desa Tambi juga terdapat Madrasah Diniyyah (Madin) sebagai wadah anak-anak didik untuk mendalami ajaran agama Islam.

b. Sikap Keagamaan

Bentuk pendampingan orang tua pada anak didiknya di desa Tambi, tidak hanya untuk membentuk perilaku keagamaan, namun juga sikap keagamaan. Sikap keagamaan adalah suatu keadaan yang ada dalam diri seseorang yang mendorong sisi orang untuk bertingkah laku yang berkaitan dengan agama. Begitu juga Zakiah Daradjat (2014: 78.) mengatakan bahwa “sikap keagamaan merupakan perolehan dan bukan bawaan. Ia terbentuk melalui pengalaman langsung yang terjadi dalam hubungannya dengan unsur-unsur lingkungan materi dan sosial, misalnya rumah tenteram, orang tertentu, teman orang tua, jamaah dan sebagainya”. 


\section{Diklus: Jurnal Pendidikan Luar Sekolah, 2(1), Maret 2018 - 17 Bima Suka Windiharta}

Sikap agama ini harus dibangun dan dikembangkan sejak anak masih kecil, agar di dalam kedewasaannya mampu untuk berperilaku keagamaan. Pendapat tersebut, mengindikasikan bahwa sikap keagamaan dikembangkan oleh pada orang tua pada anak didik agar kelak anaknya mampu menjadi panutan dan tidak menimbulkan kekhawatiran kepada anaknya sendiri. Panutan disini dapat diartikan sebagai keberlanjutan pola asuh dan pendampingan anak setelah dewasa kepada generasi selanjutnya. Sehinga generasi selanjutnya (setelah anak) dapat dengan mudah untuk direkayasa untuk bersikap religious dari sekarang.

Selain itu, bentuk wujud dari sikap beragama bisa ditunjukkan oleh para anak didik dengan mampu memahami ajaran agama dengan baik. Sebagai contoh, para anak didik mampu untuk memahami ajaran tentang sholat beserta bacaannya, rukun Iman, dan rukun Islam. Sebab bagi masyarakat desa Tambi, seorang anak yang tidak dapat menerangkan dan memahami ajaran agama, dinilai tidak berpendidikan.

Dapat dipahami jika sikap beragama yang dimaksudkan oleh masyarakat desa tambi yaitu, ketika anak didik mampu menjelaskan dan memahami ajaran agama, khususnya mengenai rukun Islam dan rukun Iman. Kedua rukun tersebut sebagai tiang agama, sehingga apabila anak didik kurang memahami akan terjadi ketidakcocokan dalam memahami ajaran agama Islam. c. Keteladanaan Keagamaan

Novan Ardi Wiyani (2013: 105) menyatakan bahwa keteladanan adalah perilaku dan sikap yang ditunjukkan orang lain dalam memberikan contoh terhadap tindakan-tindakan yang baik sehingga diharapkan menjadi panutan bagi yang menirunya. Berdasarkan hasil penelitian, orang tua di Desa Tambi sudah memberikan keteladan yang baik bagi anak didiknya yang patut untuk dicontoh (Hasil Observasi Tanggal 06 Desember 2016). Semua orang tua saling mendukung dan bekerjasama dalam segala hal untuk kebaikan anak didik Bentuk ketedanan yang dilakukan orang tua mengenai pelaksanaan nilai religius yaitu ikut serta dalam berbagai kegiatan yang dilakukan anak didik. Orang tua selalu mendukung serta membimbing anak didik agar senantiasa melakukan hal-hal yang baik.

Bentuk keteladanan yang masuk dalam dimensi kedua yaitu religious practice atau aspek peribadatan yaitu dengan mengkuti praktek kegiatan keagamaan yang diadakan di lingkungan masyarakat yaitu mengkuti sholat berjamaah dan kegiatan keagamaan.

Tujuan dari penjelasan tersebut mengarah kepada tokoh agama di desa Tambi yang dijadikan panutan untuk berperilaku baik. Para masyarakat di 


\section{Diklus: Jurnal Pendidikan Luar Sekolah, 2(1), Maret 2018 - 18 Bima Suka Windiharta}

desa Tambi menjadikan tokoh agama tersebut sebagai panutan sentral, dikarenakan kemampuan pemahaman mereka dalam bidang agama serta perilaku keagamaan yang dimilikinya.

Bentuk-bentuk tersebut merupakan pendampingan orang tua. Para orang tua akan menanyakan dan selalu mengingatkan kepada anak didiknya untuk mencontoh perilaku- perilaku tersebut kepada para pemuka agama di desa Tambi, dengan begitu sanggup untuk berlaku yang baik dan benar. Perilaku seperti menghormati dan menghargai serta saling tolong menolong selalu diajarkan oleh para pemuka dan para orang tua mengingatkan kepada anak didiknya masing-masing. Oleh karena itu, pola pendampingan tersebut mampu dijalankan dengan baik oleh para orang tua, agar anaknya tidak berperilaku negatif.

2. Nilai-nilai

$$
\text { Religiusitas }
$$

yang

Dikembangkan Pada Diri Anak Didik Di Desa Tambi

a. Nilai Ibadah

Nilai yang dikembangkan dari religiusitas selain aspek ibadah ritual seperti sholat berjama'ah yang sudah disebutkan, ada juga terdapat kegiatan yang dilakukan pada bulan Ramadhan yaitu Puasa. Kegiatan ramadhan yang ada di desa Tambi yaitu melakukan buka bersama dan sholat tarawih bersama, kegiatan ini juga masuk dalam dimensi kedua yaitu religous practice atau aspek peribatan dengan menjalankan ibadah puasa dan melakukan sholat berjamaah. Selain nilai religius kegiatan ini juga memumbukan nilai kebersamaan dan peduli sosial. Nilai kebersamaan dan peduli sosial muncul ketika mereka bersamasama melakukan buka bersama dengan menu yang sama dan ketik melakukan sholat berjamaah.

Hal ini juga dijelaskan oleh bapak Irawan, yang secara detail menjelaskan pendampingan orang tua agar menumbuh nilai ibadah yang berbentuk ibadah sosial,

"Ibadah sosial yang diterapkan di desa Tambi yaitu, saling tolong menolong antar sesama. Khususnya kalau ada kegiatan yang berbau agama mas, seperti Maulid Nabi, Isra' Mi'raj, bersih Desa setiap sebulan sekali, dan sebagainya. Mas, disini tidak membedakan anatara yang muda dan yang tua ketika tolongmenolong, semuanya berbaur menjadi satu dalam ikatan kekeluargaan. Ada juga membersihakan tempat ibadah Masjid dan Musholla, semuanya ikut berbaur menjadi satu untuk membersihkan. Dan yang paling penting, kami para orang tua mengajarkan untuk berlaku sopan santun kepada siapapun, baik tua maupun muda". (Wawancara tanggal 07 Februari 2017)

Dengan demikian nilai ibadah bisa diambil dari berbagai macam kegiatan, tidak hanya yang berkaitan dengan ibadah yang bersifat ritualistik, melainkan juga dapat diambil melalui 


\section{Diklus: Jurnal Pendidikan Luar Sekolah, 2(1), Maret 2018 - 19 \\ Bima Suka Windiharta}

kegiatan yang bersifat ibadah sosial, seperti yang sudah dijelaskan di atas.

\section{b. Nilai Jihad (Ruhul Jihad)}

Segala aktivitas di desa Tambi hamper seluruhnya dilakukan atas dasar kebutuhan akan hal itu. Sehingga mereka melakukannya dengan keikhlasan dan kesungguhan. Seperti menuntut ilmu dan bekerja. Para orang tua untuk membangkitkan kesungguhan jihad ini adalah dengan menasehati dan memberikan petuah kepada anak didiknya, dan para sesepuh juga melakukan hal itu kepada masyarakat. Atas dasar ini, apabila terdapat masyarakat ada yang tidak bersungguh- sungguh mereka akan malu dengan yang lain.

Adanya program mengaji setiap sore dan malam hari, memperkuat akan kesungguhan masyarakat desa Tambi dalam menanamkan nilai ruhul jihad tersebut. Tidak hanya para anak-anak yang masih SD, melainkan anak- anak muda mengikuti program mengaji tersebut, sehingga para orang tua tidak terlalu khawatir dengan keadaan mereka.

\section{c. Nilai Amanah dan Ikhlas}

Nilai amanah dan ikhlas yang diharapkan tertanam di dalam diri anak didik. Hal ini tentu suatu langkah yang sangat menentukan dalam perkembangan religiusitas anak didik. Terutama di era sekarang dimana amanah dan ikhlas sudah tidak dijadikan sebagai pedoman dalam kehidupan, sehingga tercipta ungkapan manusia konsumerisme dan tidak bertanggung jawab.

\section{d. Akhlak dan Kedisiplinan}

Salah satu nilai yang dapat diambil oleh anak tentang religiositas yang ditanamkan para orang tua mereka adalah seperti yang diungkapkan oleh Hudi yang orang tuanya hanya sebagai pedagang dipasar, ia mengungkapkan hal sebagai berikut:

Banyak nilai yang diperoleh dari anak tentang religiusitas ini dari alasan yang mereka ungkapkan terlihat ternyata pola didik orang tua itu sangat berperan penting dalam diri anak. Sehingga anak dapat mengerti pola tinghkah laku yang harus mereka terapkan dalam kehidupan masyarakat kelak.

\section{e. Nilai Keteladan}

Keteladanan dilakukan oleh orang tua agar dapat dijadikan contoh bagi anak didik untuk berbuat baik. Bentuk keteladan yang berkenaan dengan pelaksanaan nilai di desa Tambi yaitu keikutsertaan orang tua dalam kegiatan-kegiatan tersebut.

3. Faktor Pendukung dan Penghambat Dalam Mengembangkan Nilai-nilai Religiusitas Di Desa Tambi

a. Faktor Pendukung
1) Lingkungan desa Tambi yang kondusif 


\section{Diklus: Jurnal Pendidikan Luar Sekolah, 2(1), Maret 2018 - 20 \\ Bima Suka Windiharta}

Kondisi masyarakat desa Tambi yang terkenal dengan kualitasnya religiusitasnya memberikan nilai positif bagi pendampingan orang tua terhadap anak didik. Hal itu dibuktikan dengan beberapa tempat kajian agama Islam, seperti Madrasah Diniyyah, Taman Pendidikan Al-Qur'an (TPQ), Majlis Pengajian Ibu-ibu, dan Pendidikan Tahfidz Al-Qur'an. Semua majlis kajian pendidikan agama Islam tersebut sangat berdampak pada perkembangan religiusitas di dalam masyarakat desa Tambi. Selain banyaknya tepat kajian agama Islam di atas, kondisi sosial dan budaya desa Tambi juga berpengaruh.

2) Motivasi Orang Tua

Motivasi orang tua sangat penting bagi perkembangan anak didik, terutama dalam mengembangkan religiusitas. Motivasi orang tua yang terdapat di desa Tambi berkaitan dengan harapan-harapan kepada anak didik agar menjadi orang yang berguna dan memegang teguh ajaran agama Islam. Hal itu memungkinkan untuk dikembangkannya religiusitas pada diri anak didik, mereka mendampingi anak didik disetiap perilaku dan kegiatan anak didik, baik yang bersifat formal di sekolah maupun non formal di lingkungan masyarakat.

3) Kegiatan keagamaan di desa Tambi
Kegiatan keagamaan di desa Tambi memang cukup banyak dan padat, mulai sejak sore sampai malam hari. Anak-anak diwajibkan mengikuti pengajian tersebut. Kewajiban tersebut bukan berasal dari desa melainkan dari tradisi yang sudah membudaya di benak masyarakat desa Tambi. Para orang tua sangat terbantu dalam mendampingi anak didiknya, karena dengan adanya kegiatan keagamaan menjadi semakin terarah pola perilaku dari anak didik. Kegiatan keagamaan yang terdapat di desa banyak macamnya, ada yang berbentuk organisasi seperti IPNU-IPPNU, Anshor, dan Pemuda desa Tambi. Melainkan juga sifatnya yang kumpulan, seperti jamaah yasinan dan tahlilan.

4) Banyaknya lembaga pendidikan agama yang tersebar di desa Tambi

Lembaga pendidikan agama Islam di desa Tambi tidak hanya berfokus pada pengkajian Al-Qur'an dan Hadis. Namun mengkaji tentang wawasan dan kekayaan intelektual Islam, seperti pengkajian Kitab Kuning. Lembaga pendidikan yang ada di desa yang mempunyai peran penting adalah Madrasah Diniyyah AnNida', karena sudah sejak lama Madin tersebut telah mengajarkan ilmu-ilmu Islam dan akhlak Islam, sehingga terbentuk masyarakat yang religius seperti di desa Tambi. Selain lembaga Madin juga terdapat Taman Pendidikan 


\section{Diklus: Jurnal Pendidikan Luar Sekolah, 2(1), Maret 2018 - 21 Bima Suka Windiharta}

Al-Qur'an (TPQ) yang mengajarkan tentang segala aspek berkaitan dengan Al- Qur'an. Anak usia 6 sampai 15 Tahun menjadi target dari TPQ tersebut, agar mereka mampu membaca dan mengamalkan Al-Qur'an dengan baik dan benar.

5) Terdapat beberapa ahli agama di desa Tambi

Tokoh agama mempunyai peran yang signifikan dalam mengembangkan religiusitas. Dari tauladan mereka, maka religiusitas dapat ditiru dan diadopsi. Tokoh agama yang terdapat di desa Tambi memang lebih dari 20 orang, namun mereka satu sama lain saling berinteraksi dan menjalin kerjasama dalam memikirkan masyarakat desa. Mereka mengajarkan ajaran agama Islam melalui pengkajian yang ada di Madin, serta memberikan suri tauladan lewat perilaku sehari-hari yang ditampilkan. Banyak masyarakat desa Tambi yang tua maupun muda menghormati mereka, dan sesekali meminta wejangan-wejangan hidup.

\section{b. Faktor Penghambat}

\section{1) Budaya digital}

Era sekarang merupakan era yang serba digital. Bahkan sampai persoalan makan dan minum pun sudah dapat dilakukan secara digital. Sekarang kita semua berada pada era digital yang tanpa batas dan bebas nilai. Sehingga perlunya pengawasan terhadap anak didik menjadi bagian sangat perlu. Di desa Tambi mayoritas anak didik sudah dapat mengoperasikn dunia digital, baik computer, gadget, internet dan lain sebagainya.

2) Rendahnya kepekaan orang tua kepada anak didiknya

Faktor kedua dalam menghambat perkembangan nilai-nilai religiusitas di desa Tambi yaitu kepekaan orang tua Kepekaan disini diartikan sebagai pola kepekaan orang tua kepada anak didiknya, seperti memberikan pelajaran, mengingatkan dan sebagainya. Selama penelitian di desa Tambi penulis memperoleh keluhan dari para orang tua, yang menganggap bahwa mereka kadang lalai dan lupa terhadap tugas pendampingan tersebut.

3) Pergaulan remaja

Selanjutnya yang menjadi penghambat adalah pola pergaulan remaja saat ini yang mengalami degradasi. Sudah bukan barang yang aneh dan unik lagi, bahwa era sekarang ini mengakibatkan adanya pola perilaku dan pergaulan anak didik yang mengalami kemunduran. Pergaulan bebas mereka mengakibatkan perkembangan diri sendiri menjadi terganggu. Pergaulan bebas tidak hanya dalam bentuk perilaku, namun juga dalam pola pikir. Pola pikir menjadi semakin liberal dan radikal, 


\section{Diklus: Jurnal Pendidikan Luar Sekolah, 2(1), Maret 2018 - 22 Bima Suka Windiharta}

sehingga banyak yang melanggar batasbatas ajaran agama Islam.

4) Pekerjaan orang tua

Pekerjaan orang tua menjadi kendala terakhir dalam mendampingi perkembangan nilai-nilai religiusitas pada diri anak didik. Di desa Tambi sendiri banyak terdiri dari pekerjaan orang tua, salah satunya adalah adanya orang tua yang bekerja di luar negeri atau luar daerah, sehingga mereka merasa sangat susah dalam mendampingi perkembangan ana didiknya. Selain itu para orang tua yang bekerja di luar negeri atau luar daerah hanya satu tahun sekali pulang ke desa Tambi, sehingga mereka tidak tahu sama sekali selama satu tahun perkembangan nilai-nilai religiusitas anak didiknya.

\section{SIMPULAN DAN SARAN}

Simpulan

Simpulan yang diperoleh berdasarkan hasil penelitian yang telah diuraikan pada bab sebelumnya adalah :

1. Peranan orang tua merupakan bagian terpenting pada kehidupan anak dalam keluarga, yang dimana pada jaman sekarang ini banyak perubahan perubahan yang diterima dalam kehidupan masyarakat. Era globalisasi yang terjadi dalam masyarakat menyebabkan privasi seseorang itu tidak lagi menjadi sebuah privasi individu tetapi sudah biasa menjadi konsumsi publik. Dalam peranan orang tua ini, orang tua dituntut untuk selalu mengawasi anak mereka agar tidak terjerumus dalam kehidupan yang serba bebas.

2. Orang tua merupakan sebuah contoh atau cerminan bagi anak, jika orang tua mengajarkan hal yang baik maka anak akan menirunya. Apalagi peranan orang tua itu dibutuhkan dalam membentuk karakter anak yang akan dijadikan bekal bagi anak untuk hidup bermasyarakat kelak. Banyak cara yang ditempuh orang tua dalam membentuk karakter anak. Banyak orang tua memasukan anak mereka pada lembagalemabaga lain misalnya lembaga pendidikan yang bersifat keagamaan, hal ini dilakukan orang tua agar Anak mereka nantinya lebih mengerti betapa pentingnya agama itu dalam kehidupan mereka.

3. Jika tidak ditanamkan sejak dini, para orang tua akan khawatir kelak anak mereka tidak berguna dalam masyarakat, karena tidak ada orang tua yang mengharapkan anak mereka nantinya hanya menjadi cemooh warga masyarakat belaka. Cara-cara yang digunakan dalam mendidik anakpun sangat mendapat respon yang cukup bagus. Para orang tua di Desa Tambi dapat mendidik religiusitas anak dengan cara masa kini sehingga anak-anak dapat menerimanya dengan tulus dan tidak menganggap para orang tua mereka kuno atau ketinggalan jaman.

Saran 


\section{Diklus: Jurnal Pendidikan Luar Sekolah, 2(1), Maret 2018 - 23 Bima Suka Windiharta}

Setelah dilakukan penelitian terhadap pendampingan orang tua dalam mengambangkan nilai-nilai religiusitas pada diri anak didik di desa Tambi, maka peneliti mengajukan saran sebagai berikut :

1. Di dalam mendidik anak sebaiknya orang tua tidak terlalu keras dalam mendidik anak karena kekerasan akan menimbulkan anak menjadi berontak.

2. Jika orang tua dalam memberikan pendidikan terhadap anak dilakukan secara jarak jauh sebaiknya anak juga dapat menerimanya dengan baik meskipun jauh dari pengawasan orang tua.

3. Peneliti menyadari bahwa penelitian ini masih banyak kekurangan, maka dari itu peneliti menyarankan kepada masyarakat untuk mengadakan penelitian lain yang berhubungan dengan peranan orang tua terhadap anak dalam menerapkan religiositas terhadap anak.

\section{DAFTAR PUSTAKA}

Ahmadi, Abu. (1999). Psikologi

Sosial.Jakarta: Rineka Cipta.

Daradjat, Zakiyah. (1979). Ilmu Jiwa Agama. Jakarta: Bulan Bintang.

(2001). Peranan Agama dalam Kesehatan Mental. Jakarta: Gunung Agung.

(1998). Pendidikan Agama dalam Pembinaan Mental. Jakarta: Bulan Bintang. Hamalik, Oemar. (2010). Metode Belajar dan Kesulitan-kesulitan Belajar. Bandung: Tarsito.
Hasbullah. (2013). Pengantar Psikologi Pendidikan. Jakarta: Balai Pustaka.

Hurlock, Elizabeth. (1999). Perkembangan Anak. Jakarta: Erlangga.

Husein, Fatimah. (2008). Resonansi Dialog Agama dan Budaya. Yogyakarta:

Center For Religious \& Cross, Cultural Studies

(CRCS), Universitas Gajah Mada.

Iryanto. (2000). Pendidikan dalam Keluarga. Jakarta: Bulan Bintang.

J.P, Chaplin. (1997). Kamus Lengkap Psikologi. Jakarta: Rajawali Press.

Kartono, Kartini. (2010). Psikologi Anak (Psikologi Perkembangan). Bandung: CV. Mandar Maju

Nasution, Harun. (1995). Islam Rasional, Gagasan dan Pemikiran. Bandung: Mizan.

Paul Johnson, Doyle. (1986). Teori Sosiologi Klasik \& Modern. Jakarta: PT. Gramedia.

Phil, Astrid, S.Susanto, Pengantar Sosiologi dan Perubahan Sosial, Putra Abardin, Jakarta, 1999.

Puspito, Hendro. (1989). Sosiologi Sistematik. Yogyakarta: Kanisius.

Rakhmat, Jallaluddin. (2000). Psikologi Agama. Jakarta: PT. Raja Grafindo Persada 